\title{
In Situ Investigation of the Biodeteriorative Microorganisms Lived on Stone Surfaces of the Sumela Monastery (Trabzon, Turkey)
}

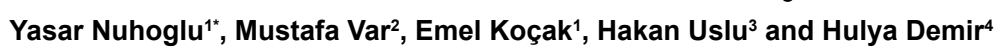

${ }^{1}$ Department of Environmental Engineering, Faculty of Civil Engineering, Yıldız Technical University, 34220, Davutpasa Campus, Istanbul, Turkey ${ }^{2}$ Department of Urban and Regional Planning, Faculty of Architecture, Yıldız Technical University, 34349, Yıldız Campus, Istanbul, Turkey

${ }^{3}$ Department of Clinical Microbiology, Medicine Faculty, Atatürk University, 25240, Erzurum, Turkey

${ }^{4}$ Faculty of Health Science, Yeditepe University, 34755 Ataşehir, Istanbul, Turkey

\begin{abstract}
In situ investigation of the biodeteriorative microorganisms lived on the Sumela monastery stones were identified using Microbial Identification System (MIS) and SEM-EDS combined system energy dispersive spectrometric investigations. The results showed that wide variety micro/macro-organisms dwell on stones of the Sumela Monastery. Total 24 species and 10 genuses were determined on the deteriorated stone surfaces by microbial identification studies. The settled way of these organisms on stone surface were illustrated by SEM images. EDS analyses show that the major elements constituting the stones of the Sumela Monastery are silicon, aluminum, calcium, potassium, titanium, magnesium, zinc, sulfur, iron, sodium and niobium. Some of these elements could provide energy resources for the microorganisms by dissolving stone-surfaces of the Monastery. However, the biodeteriorative effect of micro/macroorganisms is more significant on stones of the Sumela Monastery, we see that the man is the most destructive agents on the historical building among all of the deteriorative factors.
\end{abstract}

Keywords: Sumela monastery; Biodeterioration; Stone monuments

\section{Introduction}

The use of stone, clay and wood in monuments as construction materials is one of the principal stages in the evolution of civilization. The types of these construction materials found on the site of towns indicated development of the arts and give information about the level of civilization. As soon as a stone piece is used in stone monuments, it comes into contact with a variety of physical, chemical and biological agents which alter it. The problem of understanding the deterioration of stone is compounded by the large range of types with different mineralogical and physical characteristics and their varying weathering responses under different climatic and environmental conditions $[1,2]$.

Many agents such as physical, chemical and biological contribute to the deterioration of stone monuments, buildings, and other objects of cultural value. Degradation of stone materials under permanently open air conditions is mainly controlled by interacting chemical and mechanical processes leading to the destruction of the microstructure by the degradation processes and the propagation of micro-cracks. Degradation processes is considerably affected by the accumulation of damage resulting from time variant external loading in conjunction with environmentally induced mechanisms such as moisture and heat transport, freeze-thaw actions, chemically expansive reactions, shrinkage and chemical dissolution or by the corrosion of the reinforcement. Physical, chemical and biological agents act together, ranging from synergistic to antagonistic, in the deterioration of stone. A considerable number of investigations have begun to examine the essential role of biological agents play in the deterioration of stone [1,3-5]. The stone is susceptible to colonization by several microorganisms such as bacteria, fungi, algae, cyanobacteria and more complex organisms such as lichens and mosses responsible for a series of mechanical and chemical processes that cause the biodeterioration of the stone. The relative effects of each of these organisms vary according to the topoclimatic environmental conditions, the stone type, its state of preservation and its position on the monument [6-8]. On the other hand, pore size, distribution and specific surface area together with the capillarity of a stone control the mechanical degradation caused by water, salts, and bacteria. Understanding the complex interactions between these microorganisms and their mineral substrate is a topic of current interest, since it may shed light on the bio-weathering of stone monuments $[4,5]$.

Stone monuments and the other building materials exposed to open air deteriorate due to natural causes named as weathering agents such as temperature, rain, snow, moisture, wind and sunlight. These agents will incite both physical and chemical weathering processes [4,5,9-12]. The first affect the stability of the rock matrix, while the second act through chemical corrosion of the stone-forming minerals, such as oxidation and hydration reactions as well as dissolution of carbonates and solubilization of some elements from silicate bearing minerals. In addition to physical and chemical factors, microorganisms play a contributing role in deterioration of stone monuments [4,13]. Microbial colonization of buildings causes aesthetic and physical damage to the structure through the formation of biofilms, which contain microorganisms and their metabolic products, such as extracellular polymeric materials (EPS), and both inorganic and organic acids $[7,14,15]$.

Biodeterioration has usually been considered to be a degradation process following the initial deteriorating effects of inorganic agents. These agents were thought to condition stone surfaces for microbial contamination due to structural changes and the enrichment of inorganic and organic nutrient substrates. Microorganisms have recently been recognized as potentially significant players in the decay of buildings and artwork. A wide variety of microorganisms such as chemoheterotrophic bacteria, chemolithotrophic bacteria, phototrophic bacteria, algae, fungi

*Corresponding author: Yasar Nuhoglu, Department of Environmental Engineering, Faculty of Civil Engineering, Yıldız Technical University, 34220, Davutpasa Campus, Istanbul, Turkey, Tel: +902123837070; E-mail: ynuhoglu@yildiz.edu.tr

Received August 08, 2017; Accepted August 20, 2017; Published August 26, 2017

Citation: Nuhoglu Y, Var M, Koçak E, Uslu H, Demir H (2017) In Situ Investigation of the Biodeteriorative Microorganisms Lived on Stone Surfaces of the Sumela Monastery (Trabzon, Turkey). J Environ Anal Toxicol 7: 506. doi: 10.4172/2161. 0525.1000506

Copyright: @ 2017 Nuhoglu Y, et al. This is an open-access article distributed under the terms of the Creative Commons Attribution License, which permits unrestricted use, distribution, and reproduction in any medium, provided the original author and source are credited. 
Citation: Nuhoglu Y, Var M, Koçak E, Uslu H, Demir H (2017) In Situ Investigation of the Biodeteriorative Microorganisms Lived on Stone Surfaces of the Sumela Monastery (Trabzon, Turkey). J Environ Anal Toxicol 7: 506. doi: 10.4172/2161-0525.1000506

and lichens dwell on historical buildings and artwork. Among these, the photosynthetic microorganisms are potentially the most aggressive due to their photoautotrophic nature. Once established on stone surfaces, they permit the growth of more complex microbial flora formed by heterotrophic microorganisms, and these often activate strongly deteriorating effect. Therefore, photosynthetic microorganisms participate in decay processes directly, causing aesthetic damages and subsequently structural damages, and also indirectly, by supporting the growth of other microorganisms $[4,16]$.

The weathering characteristics of stones related to their bioreceptivity and its depend on chemical nature, physical structure and geological origin of stones such as volcanic, sedimentary and metamorphic rocks. At the same time, microbial colonization of stones depends on environmental factors, such as water availability, $\mathrm{pH}$, climatic exposure, nutrient sources, and on petrologic parameters, such as mineral composition, type of cement as well as porosity and permeability of the rock material [4].

Historical monuments are one of the most important values of cultural heritage. In this context, the Sumela Monastery had been begun $4^{\text {th }}$ century for devoted in honour of the Virgin Mary as a represent a special civilization. This marvelous stone monument was plundered sometimes by the robbers of historical-heritages belonging to various nations, and at the same time the monuments was exposed to the biodeteriorating agents. This research aimed to determining of the micro/macro-organisms lived on stone surfaces and its biodeteriorative effects on the marvelous stone monuments: the Sumela Monastery.

\section{Materials and Methods}

\section{Site description}

The Sumela (Meryemana, the Virgin Mary) monastery is in
Altındere village of Macka district $\left(40^{\circ} 47^{\prime} \mathrm{N}, 39^{\circ} 36^{\prime} \mathrm{E}\right.$, elevation $1100 \mathrm{~m}$ ), $48 \mathrm{~km}$ from Trabzon in the East Black Sea Region of Turkey. This region was established as Sumela National Park by the Republic of Turkey Ministry of Environment and Forestry. Macka town is known a monastery site along the Black Sea Region, and it has four unique monasteries such as Sumela, Vezelon, St. Barbara and Kustul (St. George Peristere). The Sumela monastery was built in a huge cave placed in the middle of very steep rock such straight as a wall (Figure 1). The monastery looks like it has been taken down from the sky and pasted on the side of the hill. The most important site in monastery is located above a valley inside the Pontic mountains and is reached after a pleasant ride with beautiful views of nature. This place is known as "Meryemana" by the local people.

Building of the Sumela Monastery had been begun $4^{\text {th }}$ century and its building stages continued at $13^{\text {th }}$ and $19^{\text {th }}$ century with additional units. The Monastery founded in honour of the Virgin Mary. It is said that "Sumela" comes from the word "melas", which means "dark" or "black". No one has been able to answer the question of how mankind was able to build such a huge monastery on the wall of a mountain with the technology of the $4^{\text {th }}$ century. The access to the monastery is through a narrow gate at the top of stairs cut into the rock (Figure 2).

The monastery complex had 5 floors and a total of 72 rooms (Figure 3). The internal walls of the church were full of frescoes and mural paintings (Figure 4). It was built in cutting huge rocks at lonely mountains so that the clergies could worship away from man. The spring-water issuing from the nearest rock of the Monastery were consented as sacred. The Monastery repaired many times from first building date, and the finally reparation performed in 1860, but this unique historical buildings was plundered many times by the robbers of historical-heritages belonging to various nations. It has been restored by The Ministry of Culture and Tourism Republic of Turkey according

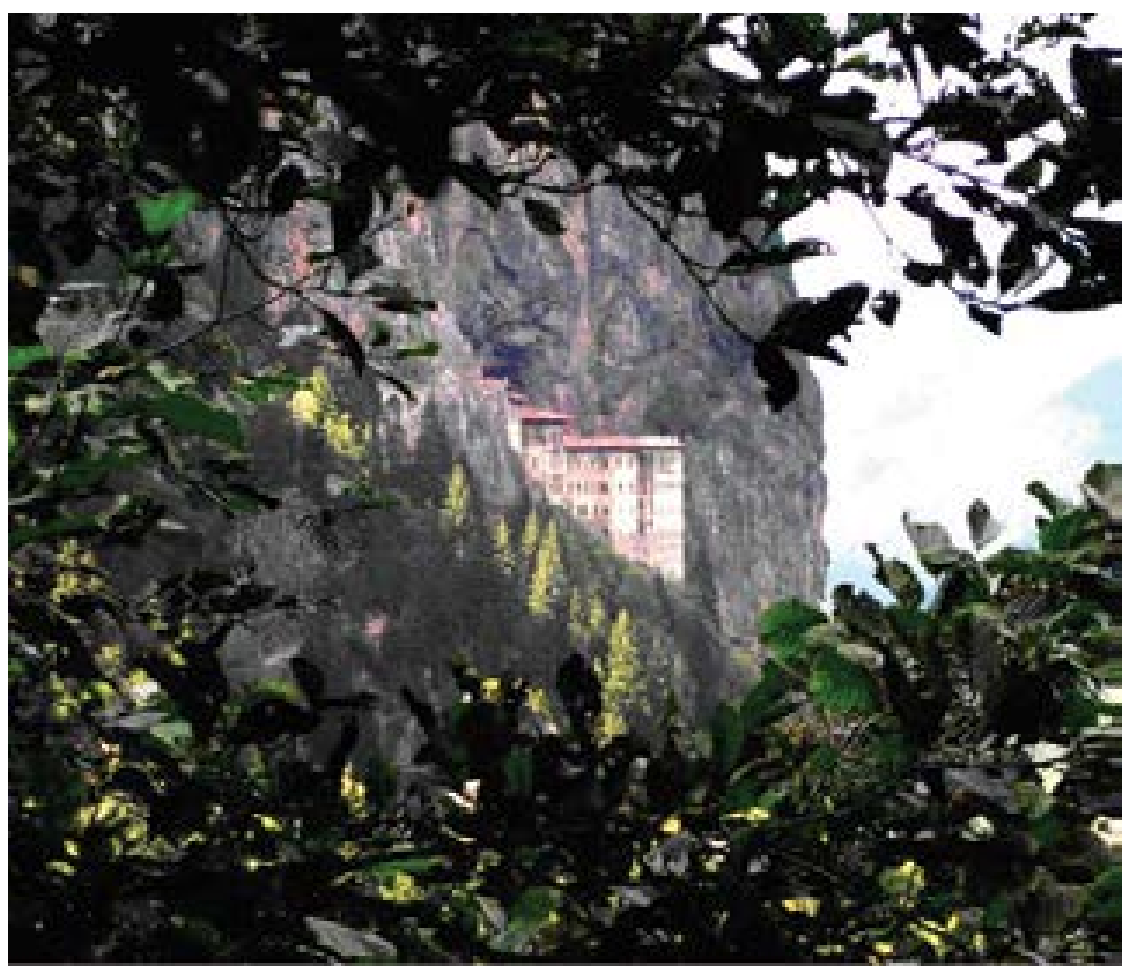

Figure 1: The view of Sumela Monastery. 
Citation: Nuhoglu Y, Var M, Koçak E, Uslu H, Demir H (2017) In Situ Investigation of the Biodeteriorative Microorganisms Lived on Stone Surfaces of the Sumela Monastery (Trabzon, Turkey). J Environ Anal Toxicol 7: 506. doi: 10.4172/2161-0525.1000506

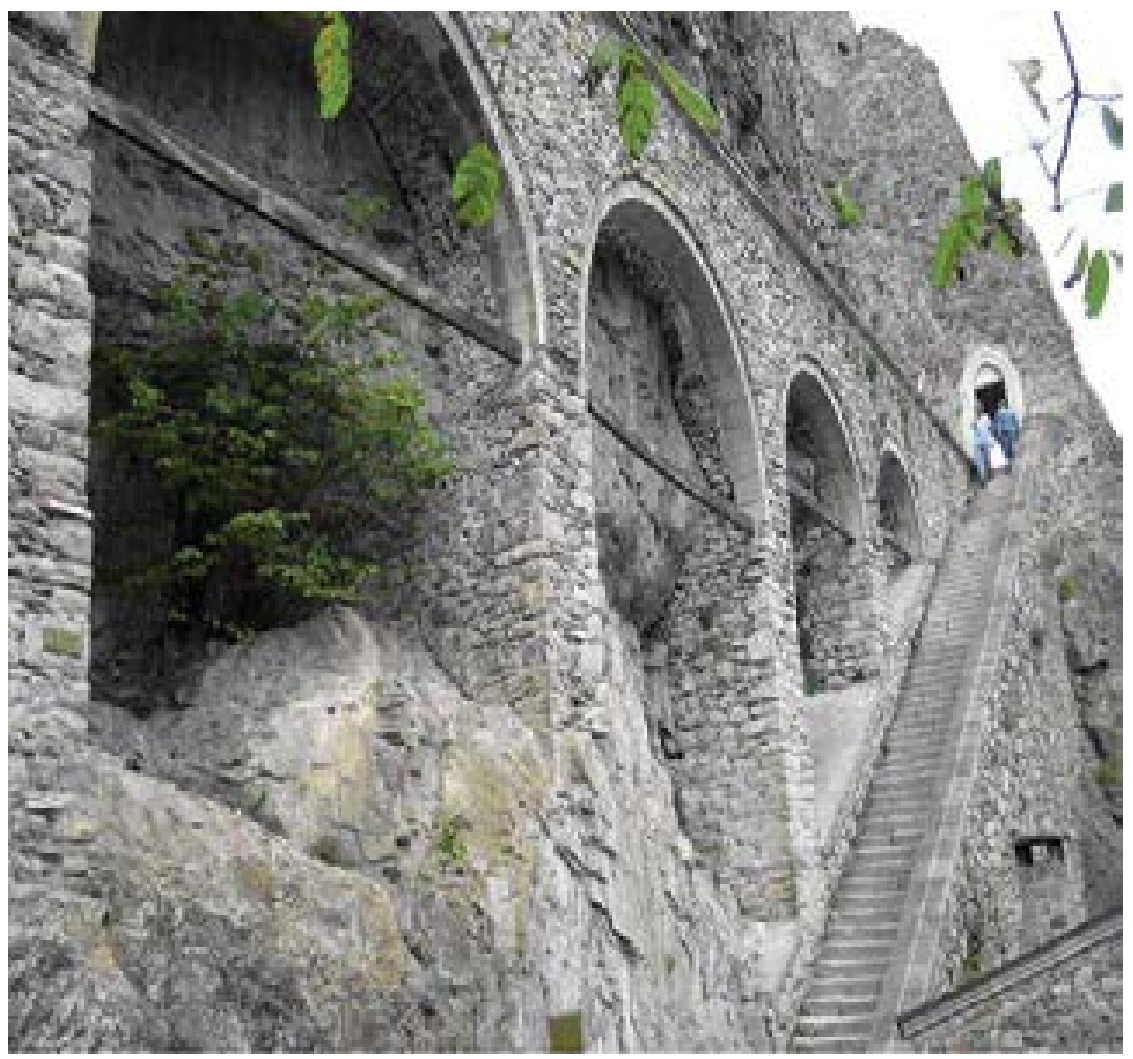

Figure 2: The access to the monastery.

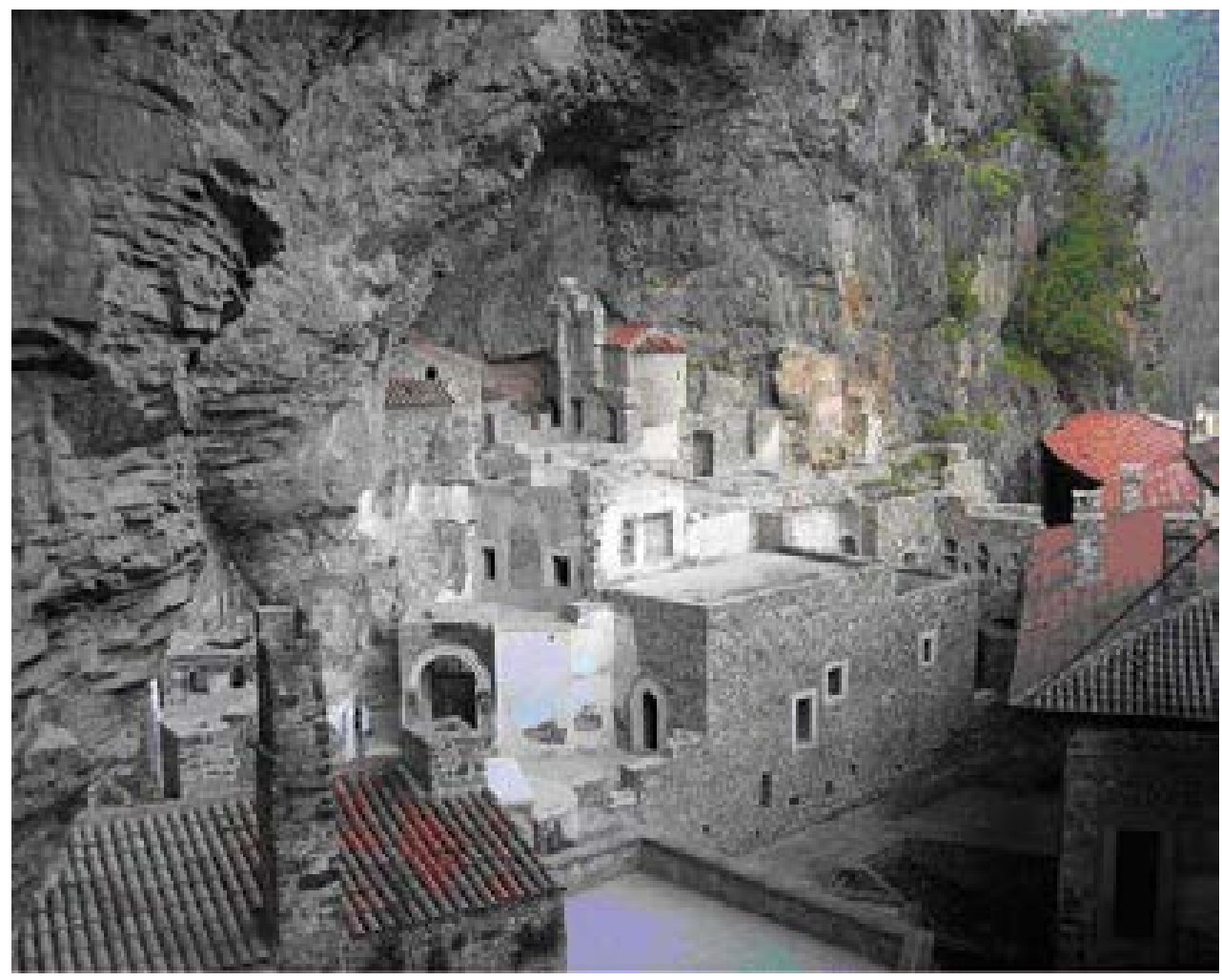

Figure 3: The monastery rooms in the cave. 
Citation: Nuhoglu Y, Var M, Koçak E, Uslu H, Demir H (2017) In Situ Investigation of the Biodeteriorative Microorganisms Lived on Stone Surfaces of the Sumela Monastery (Trabzon, Turkey). J Environ Anal Toxicol 7: 506. doi: 10.4172/2161-0525.1000506

Page 4 of 10
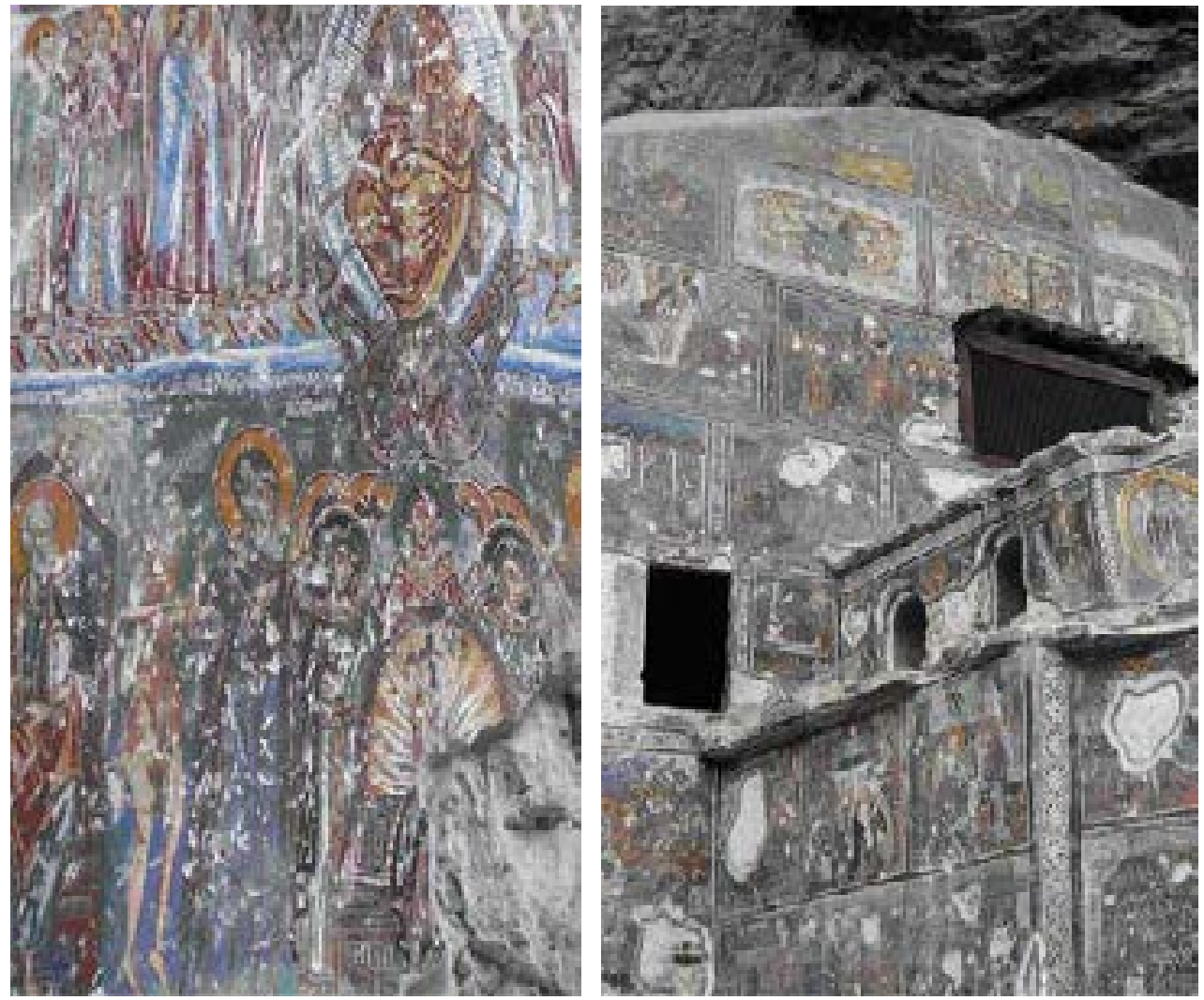

Figure 4: The frescoes and mural paintings on the Monastery walls. The some parts of the frescoes were stolen to take apart various countries.

to the original forms now. Although the famous monument isn't registered on the World Heritage List until now, it forms marvelous architectural complexes (Figures 1-4). 1 [17].

The meteorological characteristics of the Sumela are given in Table

The Sumela Monastery was built two originated stones: volcanic such as volcanic lava, andesite and trachide, and sediment as travertine. Volcanic stone is the main construction materials of the main walls of the Monastery for their durability. Sediment rocks were used as internal architectural building materials of the room-door, window domes and fresco for easy cutting peculiarities. Bricks is also used some vaults and domes.

\section{Sample collection}

The Sumela Monastery are protected by staff of the Sumela National Park, therefore the amount of sampled material was restricted especially internal parts of the monuments i.e., frescoes and mural paintings. Samples were collected according to two criteria: exposure to light (indoor and outdoor sections), and type of stone material. The four and the two sampling points were selected on external and internal parts of the monuments respectively in April 2004. Because it may be the contamination stemming from soil and ground at lower stone surface, the samples were taken from lower and upper parts of the walls. The samples were taken from about the 1 and 4 meter-high of the internal and external wall of the Monastery by means of knife, spatula and mini-hammer, and they were put into the Petri dish (and in lidded-polyethylene bags sterilized by UV-radiation). All sampling studies were carried out in aseptic conditions. There weren't differences for open-air conditions between internal and external walls of the Monastery because of devastation of monastery roof. Therefore, the internal walls exposed to open-air conditions.

Two different types of specimen were taken from the stone surface in each sample-taking point of the monuments. The first one of them (disaggregated) was taken by means of the erasing of samples from the stone surface. These samples were used bacterial and fungal identification studies. All microbiological studies were carried out in sterile conditions. The second type non-crumbed (aggregated) stone samples were taken and used in not only the identification of algae and lichens but also microscopic investigation and elemental analyses in the JEOL 6400 SEM-EDS combined system energy dispersive spectrometer.

\section{Identification of lichens and algae}

The lichens were identified by microscopic observation of the diagnostical characters such as thallus and reproductive organs of the various characteristics of the corpus by followed general keys [18]. Determination of the algal species was performed through direct observation by optical microscopy; taxonomic identification was drawn from a number of monographs [19].

\section{Identification of bacteria and fungi}

For identification of the fungi, a small portion of each specimen mounted in a few drops of $20 \%$ potassium hydroxide was examined for the presence of characteristic fungal elements and diagnostic morphology. The samples were cultured on sabouraud dextrose agar 
Citation: Nuhoglu Y, Var M, Koçak E, Uslu H, Demir H (2017) In Situ Investigation of the Biodeteriorative Microorganisms Lived on Stone Surfaces of the Sumela Monastery (Trabzon, Turkey). J Environ Anal Toxicol 7: 506. doi: 10.4172/2161-0525.1000506

Page 5 of 10

\begin{tabular}{|c|c|c|c|c|c|c|c|c|c|c|c|c|c|}
\hline \multirow[t]{2}{*}{ Meteorological Parameters } & \multicolumn{13}{|c|}{ Months } \\
\hline & 1 & 2 & 3 & 4 & 5 & 6 & 7 & 8 & 9 & 10 & 11 & 12 & Average \\
\hline Temperature $\left({ }^{\circ} \mathrm{C}\right)$ & 4.5 & 4.9 & 6.8 & 11.5 & 14.5 & 17.8 & 20.1 & 20.2 & 17.5 & 13.3 & 9.6 & 5.7 & 12.2 \\
\hline Precipitation $(\mathrm{mm})^{*}$ & 45 & 47 & 51 & 103 & 125 & 130 & 92 & 91 & 68 & 81 & 56 & 53 & $902.0^{*}$ \\
\hline Moisture (\%) & 70 & 70 & 70 & 73 & 77 & 80 & 82 & 82 & 81 & 78 & 74 & 72 & 76 \\
\hline
\end{tabular}

*Total

Table 1: The average of some meteorological parameters of Sumela.

containing peptone $(10 \mathrm{~g})$, glucose $(20 \mathrm{~g})$ and agar $(15 \mathrm{~g})$. The medium was supplemented with chloramphenicol and cycloheximide (50 and $500 \mathrm{mg} / \mathrm{dl})$. The cultures were incubated at $26^{\circ} \mathrm{C}$ and examined twice a week for a total duration of 4 weeks. After that, the isolates were passed through tubes into Petri dishes containing sabouraud dextrose agar and potato dextrose agar. The isolates were examined macroscopically, and microscopically following staining with lactophenol cotton blue. The identification of yeast was based on their macroscopic characteristics as a result of germ tube tests and biochemical tests. The identification of molds was based on their macroscopic characteristics (growth period, colony morphology, production of pigment on the back of the colony), microscopic arrangements (characteristics hyphae formation, types of conidia, sizes and shapes of the sterigmata, hyphae and organs of reproduction) and biochemical tests [5].

The identification of yeast was based on their macroscopic characteristics on result of germ tube tests and biochemical tests. The identification of the mold was based on their macroscopic characteristics (growth period, colony morphology, production of pigment on the back of the colony), microscobic arrangements (characteristics hyphea formation, types of conidia, sizes and shapes of the sterigmata, hyphea and organs of proliferation) and biochemical tests [5].

Determination of the bacterial isolates was performed through the gaschromatography method in the Microbial Identification System (MIS) that is based on bacterial fatty acid methyl ester profiling [5]. First, all samples were incubated in bbrain heart infusion brothQ to enrich bacterial growth at room temperature $\left(26 \pm 2^{\circ} \mathrm{C}\right)$ for $8 \mathrm{~h}$. After incubating each cultures, $1 \mathrm{ml}$ suspension was transferred to $5 \%$ blood agar and "btrypticase soy broth agar (TSBA)" media and incubated at room temperature $\left(26 \pm 2^{\circ} \mathrm{C}\right)$ for $24 \mathrm{~h}$ to be identification by MIS. In the identification by MIS, the subcultures of bacteria on the $5 \%$ blood agar and TSBA medium were used. Cultures were extracted by saponification, and methylation. The extracts were subsequently washed with bases. The extractions were performed in one batch simultaneously, in order to reduce the differences caused by environmental conditions. The saponification reagent consisted of sodium hydroxide, methanol (HPLC grade), and deionized distilled water. Methylation reagent was $6 \mathrm{~N}$ hydrochloric acid in methanol (HPLC grade). Ingredients of the extraction solvent was hexane (HPLC grade), methyl-tert butyl ether (MTBE) (HPLC grade). The base washing step was carried out using diluted $\mathrm{NaOH}$. After the wash step, the extract was transferred to a special gas chromatography sample vial containing anhydrous sodium sulfate according to the manufacturer's instructions. Whole-cell fatty acids were extracted and analyzed as methyl ester derivatives. The fatty acid profiles were analyzed using "The Sherlock Microbial Identification System 7673”. The Sherlock MIS chromatographic unit consists of a Hewlett-Packard 6890 Gas Chromatograph, a 7673 Automatic Sampler (with injector, controller, and tray), and Hewlett-Packard Chemstation software. The fatty acids extracted from the microorganisms were automatically quantified and identified by MIS and the fatty acid profiles were determined and compared to a library of reference organisms in the database to identify our bacteria.

\section{SEM micrographic examinations}

Specimens taken from the sampling sites were broken into small pieces under aseptic conditions. Then, conductivity of external surfaces of the stone samples was provided by sputtering with Au-Pd target using a sputter-coater and thus the samples were ready to be examined as natural form in JEOL 6400 SEM-EDS combined system energy dispersive spectrometer. After the samples coated in a nanometer degree were attached in the holder of SEM, they were placed into the vacuum chamber to photograph and elemental analysis (EDS). Secondary electron images and energy dispersive spectrums were obtained at $10 / 25 / 30$ and $25 \mathrm{keV}$ energy level respectively. SEM micrographs were taken between 50-7,000X magnifications.

\section{Results and Discussion}

Building of the Sumela Monastery had been begun $4^{\text {th }}$ century for devoted in honour of the Virgin Mary. Some parts of this marvelous stone monument was plundered many times by the robbers of historical-heritages belonging to various nations (Figures 4 and 5), and at the same time the monuments was exposed to the biodeteriorating agents because of open-air conditions. The Sumela Monastery is strictly protecting by staff of the Sumela National Park now. In particular, this research aims the interactions between the microbial community and its biodeteriorative effects on stones of the Sumela Monastery.

Our observations indicated that the external walls of the Sumela Monastery showed clear indications of biodeterioration, including stone disaggregation and the presence of lichens and mosses which were abundantly colonized on the lower parts of the walls and free stones (Figure 6). Algal and fungal cells were very abundant in the internal fragments of the splitting rock (Figure 7). Many white spots due to lichens were observed on the stone surfaces. The stone surface is frequently deteriorated due to the action of algae and lichens. It is well known that acid secreted by algae and lichens accelerates the deterioration of stone surfaces $[4,20]$.

When applied in situ, scanning electron microscopy (SEM) is an ideal method of observing biofilms and diagnosing their effects on stone monuments $[2,21]$. The SEM images showed us how the thalli were closely attached to the internal fragments of the splitting rock and substrates (Figure 7). Fungal hyphae and algal cells could be seen in the inner substrate areas. It seen in Figures 6 and 7 that the biodeterioration of the Sumela Monastery stones is the result of complex microbial interactions in the microbial consortia and not the consequence of the action of a particular group of microorganisms.

By means of the microbial identification studies, the following species and genus of microorganisms were determined the stone surfaces and pores of the Sumela Monastery in April 2004 (Table 2). As seen in Table 2, a total of $34 \mathrm{micro} /$ macro-organism taxa were identified, of which 10 were identified to genus level, 24 to species level.

Examination of Table 2, and carried out in situ investigation, it is seen that the species of lichens such as Umbilicaria cinereorufescens (Figure 8), Candelariella vitellina, the genus of licken such as Collema 
Citation: Nuhoglu Y, Var M, Koçak E, Uslu H, Demir H (2017) In Situ Investigation of the Biodeteriorative Microorganisms Lived on Stone Surfaces of the Sumela Monastery (Trabzon, Turkey). J Environ Anal Toxicol 7: 506. doi: 10.4172/2161-0525.1000506

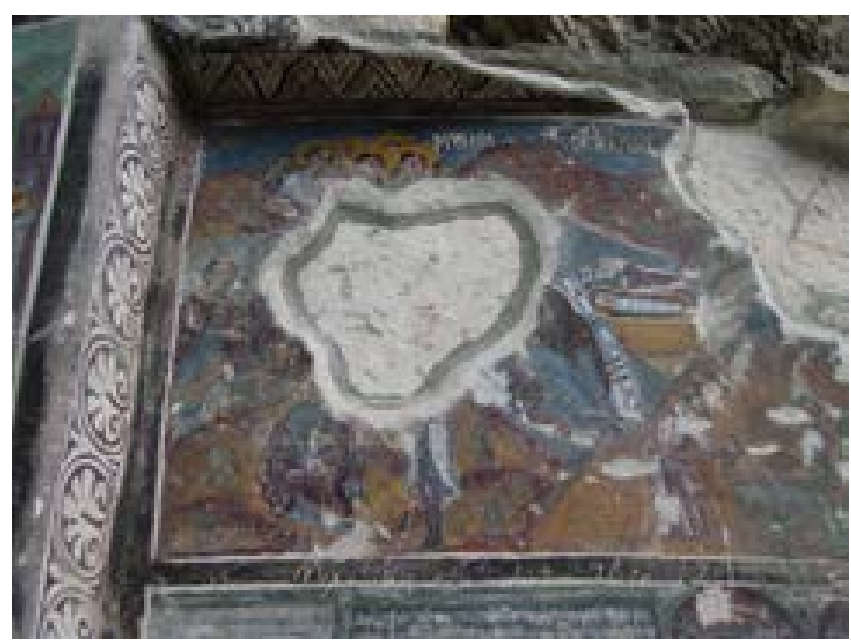

Figure 5: The stolen parts of frescoes of the Sumela monastery. The stolen parts have been presented by various persons and museums.

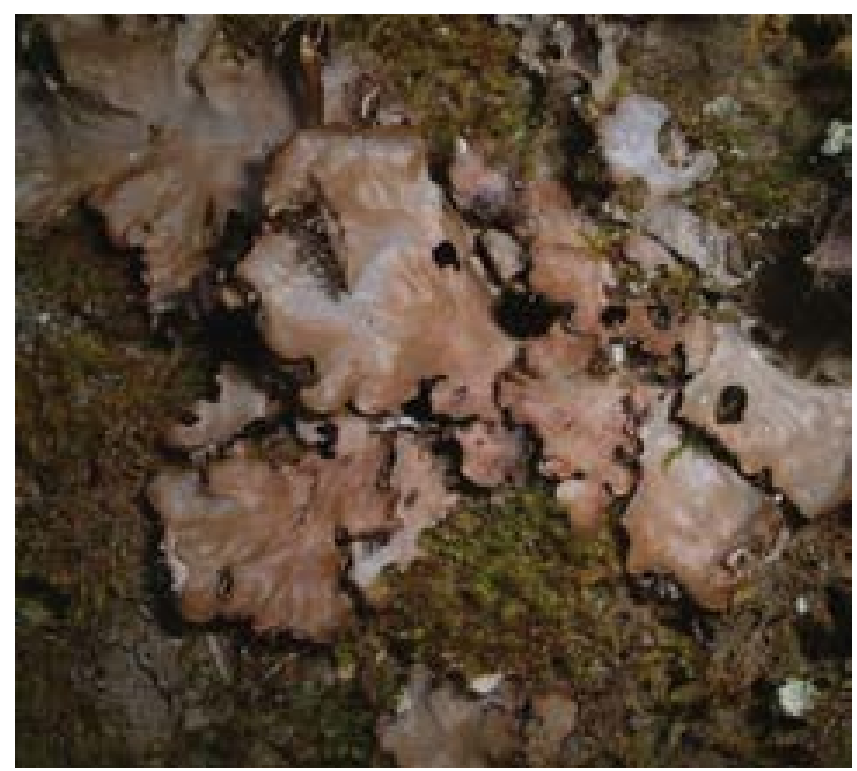

Figure 6: The colonization of lichens and mosses on the lower parts of the Monastery walls.
Sp. (Figure 9), Physcio sp. and Lecidea sp., the genus of algae such as Pleurococcus sp., Chlorella sp., Chrococcus sp. and Nostoc sp., the species of fungi such as Fusarium dimerum, Acremonium strictum and Aspergillus terricola, the species of bacteria such as Bacillus subtilis, Bacillus coagulans, Bacillus thuringiensis sotto, Paenibacillus larvaepulvifaciens and Virgibacillus pantothenticus widely live on the lower parts of the monastery walls. These microorganisms develop depending on relatively intensive moisture and soil derived enrichment nutrients that contamination of soil particles, including organic and inorganic nutrients. They were sprinkled by abundant rainfall from the ground or were dragged by wind from the top of the steep rock.

The genus of lichens such as Verrucaria sp. and Chrysothrix sp., the species of fungi such as Alterneria alternata and Penicillium verrucosum var. cyclopium, the species of bacteria such as Bacillus agri, Bacillus cereus, Bacillus mycoides, Bacillus lentimorbus, Brevibacillus laterosporus and Paenibacillus apiarius widely live on the upper surface of the Monastery walls. The species of bacteria such as Streptoverticillium reticulum, Arconobacterium haemolyticum live on both bottom and

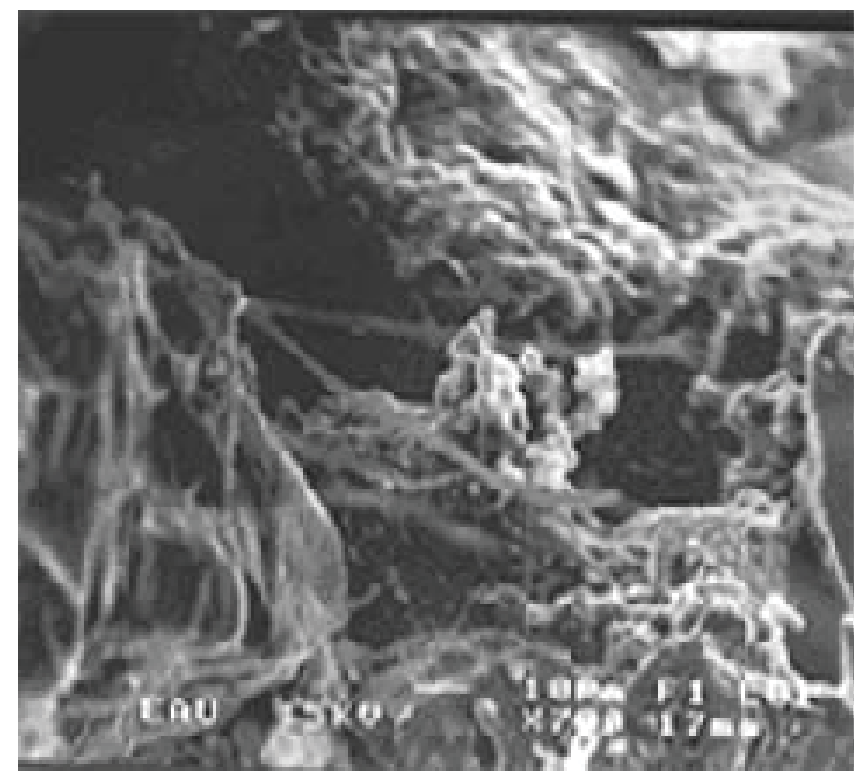

Figure 7: The SEM image of microbial consortia located on the internal fragments of the splitting rock.

\begin{tabular}{|c|c|c|c|c|c|c|c|c|c|c|c|c|}
\hline \multirow[t]{3}{*}{ The species and groups of microorganisms } & \multicolumn{12}{|c|}{ The sample points* } \\
\hline & \multicolumn{8}{|c|}{ External wall } & \multicolumn{4}{|c|}{ Internal wall } \\
\hline & \multicolumn{2}{|c|}{ The $1^{\text {st }}$} & \multicolumn{2}{|c|}{ The $2^{\text {nd }}$} & \multicolumn{2}{|c|}{ The $3^{\text {rd }}$} & \multicolumn{2}{|c|}{ The $4^{\text {th }}$} & \multicolumn{2}{|c|}{ The $5^{\text {th }}$} & \multicolumn{2}{|c|}{ The $6^{\text {th }}$} \\
\hline Lichens & $1 \mathrm{~m}$ & $4 m$ & $1 \mathrm{~m}$ & $4 m$ & $1 \mathrm{~m}$ & $4 m$ & $1 \mathrm{~m}$ & $4 m$ & $1 \mathrm{~m}$ & $4 m$ & $1 \mathrm{~m}$ & $4 m$ \\
\hline Candelariella vitellina & + & - & + & - & - & - & + & - & + & - & - & - \\
\hline Lepraria incana & + & - & + & + & + & - & - & + & - & - & - & - \\
\hline Xanthoria elegans & + & - & + & + & - & - & + & - & + & - & - & - \\
\hline Umbilicaria cinereorufescens & + & - & - & - & + & + & - & - & - & - & - & - \\
\hline Verrucaria sp. & - & + & - & + & - & + & - & - & - & + & - & - \\
\hline Lecidea sp. & - & - & + & - & - & - & + & - & + & - & - & - \\
\hline Chrysothrix sp. & + & + & - & + & + & - & + & + & - & + & - & - \\
\hline Dermatocarpon sp. & + & - & - & + & + & - & - & + & - & + & - & - \\
\hline Collema sp. & + & - & + & - & + & + & - & + & - & - & - & - \\
\hline Physcio sp. & - & + & - & + & - & + & - & + & - & + & - & - \\
\hline
\end{tabular}


Citation: Nuhoglu Y, Var M, Koçak E, Uslu H, Demir H (2017) In Situ Investigation of the Biodeteriorative Microorganisms Lived on Stone Surfaces of the Sumela Monastery (Trabzon, Turkey). J Environ Anal Toxicol 7: 506. doi: 10.4172/2161-0525.1000506

Page 7 of 10

\begin{tabular}{|c|c|c|c|c|c|c|c|c|c|c|c|c|}
\hline \multicolumn{13}{|l|}{ Algae (including Cyanobacteria) } \\
\hline Pleurococcus sp. & + & - & - & - & + & - & - & - & - & - & - & - \\
\hline Chlorella sp. & - & - & + & - & - & - & + & - & - & - & + & - \\
\hline Chrococcus sp. & + & - & - & - & + & - & - & - & + & - & - & - \\
\hline Nostoc sp. & - & - & + & - & + & - & + & - & + & - & - & - \\
\hline \multicolumn{13}{|l|}{ Fungi } \\
\hline Alterneria alternata & - & + & - & + & - & - & - & - & - & - & - & - \\
\hline Fusarium dimerum & + & - & + & - & + & - & - & + & + & - & + & - \\
\hline Acremonium strictum & + & - & - & - & + & - & + & - & - & - & - & - \\
\hline Penicillium jensenii & - & - & - & - & + & - & + & - & - & + & - & + \\
\hline Penicillium verrucosum var. cyclopium & - & - & - & + & - & - & - & - & - & - & - & + \\
\hline Aspergillus terricola & - & - & + & - & - & - & - & - & + & - & + & - \\
\hline \multicolumn{13}{|l|}{ Bacteria } \\
\hline Bacillus subtilis & + & + & - & - & + & - & + & - & - & - & - & - \\
\hline Bacillus agri & - & + & - & + & - & - & - & + & - & - & - & - \\
\hline Bacillus cereus & - & + & - & + & + & - & - & + & - & - & - & - \\
\hline Bacillus licheniformis & - & + & - & + & + & - & + & - & - & - & - & - \\
\hline Bacillus mycoides & - & - & - & - & - & - & - & - & - & + & - & + \\
\hline Bacillus coagulans & + & - & - & - & - & - & + & - & - & + & - & - \\
\hline Bacillus lentimorbus & - & - & - & - & - & - & & & - & + & - & + \\
\hline Bacillus thuringiensis sotto & + & - & - & - & + & - & + & - & - & - & - & - \\
\hline Brevibacillus laterosporus & - & + & - & + & + & - & - & - & - & - & - & - \\
\hline Streptoverticillium reticulum & + & + & - & + & - & - & + & - & - & - & - & - \\
\hline Arconobacterium haemolyticum & + & - & - & - & - & - & - & - & - & + & - & - \\
\hline Paenibacillus larvae-pulvifaciens & + & - & - & - & + & - & + & - & - & + & - & - \\
\hline Paenibacillus apiarius & - & - & - & - & - & - & - & - & - & + & - & + \\
\hline Virgibacillus pantothenticus & + & - & - & - & + & - & + & - & - & - & - & - \\
\hline
\end{tabular}

"The samples taken from the $1^{\text {st }}$, the $2^{\text {nd }}$, the $3^{\text {rd }}$ and the $4^{\text {th }}$ sampling point belonging to the three different external walls of the Monastery, and the $5^{\text {th }}$ and the $6^{\text {th }}$ sampling points belonging to the window domes of the internal walls and swelled-parts of the fresco of the Sumela monastery respectively. Only the stones of the $5^{\text {th }}$ sampling points were sediment (travertine) and the others except for fresco were volcanic.

Table 2: The microbial flora determined on the stone surfaces of the Sumela Monastery.

\begin{tabular}{|c|c|c|c|c|c|c|c|c|c|c|c|}
\hline \multirow[t]{2}{*}{ Stone type } & \multicolumn{11}{|c|}{ The elemental analyses of the stone samples (weight \%) } \\
\hline & Si & $\mathbf{A l}$ & $\mathrm{Ca}$ & $\mathbf{K}$ & Mg & $\mathrm{Zn}$ & $\mathbf{S}$ & $\mathrm{Na}$ & Mn & $\mathrm{Nb}$ & Others* \\
\hline Granitic 1 (External wall) & 29.20 & 8.34 & 1.88 & 1.18 & 1.50 & 0.50 & - & 0.48 & 7.76 & 2.76 & 46.40 \\
\hline Granitic 2 (External wall) & 22.95 & 8.57 & 5.20 & 2.96 & 1.43 & 1.51 & - & 2.76 & 0.46 & 1.70 & 52.46 \\
\hline Sediment (Internal wall) & 7.68 & 2.69 & 37.12 & 0.56 & 2.45 & 3.32 & 2.87 & - & - & 7.35 & 35.96 \\
\hline
\end{tabular}

"These elements are carbon, hydrogen, oxygen and little amounts of non-detectable elements.

Table 3: The elemental analyses of the stone samples taken from the 4-meters-high parts of the Sumela Monastery.

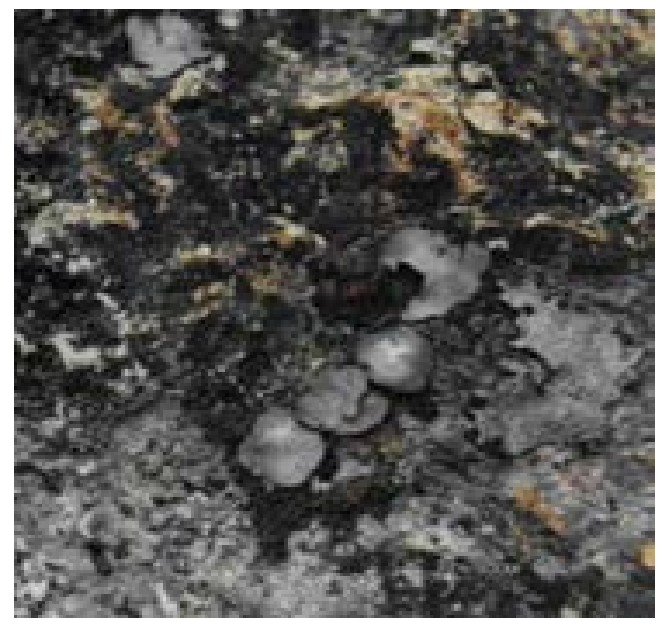

Figure 8: The colonization of Umbilicaria cinereorufescens on the monastery wall.

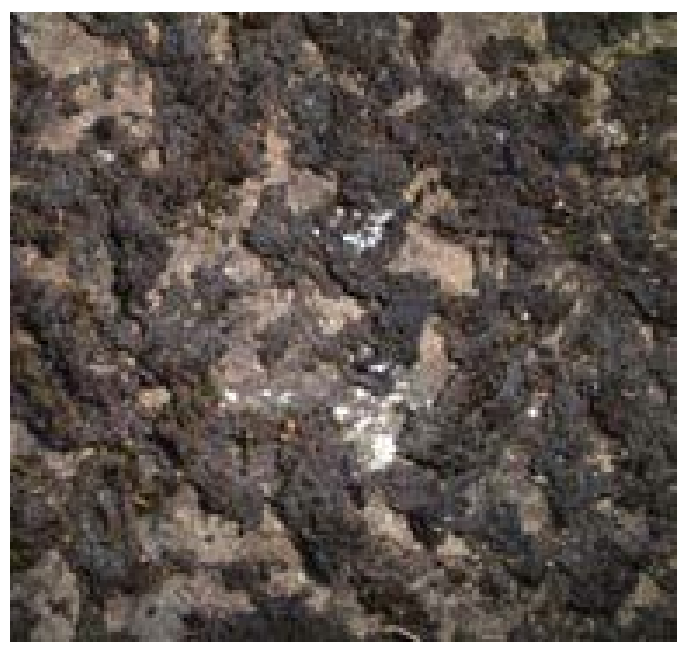

Figure 9: The colonization of Collema sp. 
Citation: Nuhoglu Y, Var M, Koçak E, Uslu H, Demir H (2017) In Situ Investigation of the Biodeteriorative Microorganisms Lived on Stone Surfaces of the Sumela Monastery (Trabzon, Turkey). J Environ Anal Toxicol 7: 506. doi: 10.4172/2161-0525.1000506

upper surfaces of the Monastery walls, and Penicillium jensenii lived on bottom surfaces of volcanic rock and upper surfaces of sediment rocks of the Monastery walls. The species of lichen such as Xanthoria elegans (Figure 10), Lepraria incana (Figure 11) and Dermatocarpon sp., and the species of bacteria as Bacillus licheniformis live on bottom and upper surfaces.

Stone surface is a poorer enrichment media than humus contained soil for the microorganisms [4,5,22]. The microorganisms lived on soil sprinkled stone surfaces, lived on bottom parts of the Monastery walls, is dependent to soil derived inorganic/organic nutrients more than the microorganisms lived on upper parts of Monastery walls. For this reason, the bottom stone-surface, which permits the growth of more complex and intensive macro/microbial flora, are exposed to more biodeteriorative effects than the upper surfaces of the Monastery because of existing soil derived nutrients besides weathering agents (Figure 6). In other words, the upper stone-surface living microorganisms have to reconcile only the stones (poorer enrichment media) to soil derived nutrients, and so the development of the microflora can be restricted the poorer conditions. However, bottom stone-surface living microbial communities that develop associated with chemical and physical weathering factors may be more affective agents from the upper stone surface in the Sumela Monastery.

The elemental analyses of the stones and the secondary electron images (SEI) of the stone-surfaces on the Monastery, examined by means of SEM-EDS combined system energy dispersive spectrometry, are shown in Table 3 and Figures 7 and 12 respectively. SEM image of complex microbial consortia on volcanic stone in the 1 meter-high of the external wall of $3^{\text {rd }}$ sampling point was shown in Figure 7. A dense mycelial growth of Penicillium sp. covers the surface of the stones and presents a very colonizing situation of sub-aerial biofilm. Thin filaments of actinomycetes develop together with fungus in near location. The stone-surface were covered with full of fungal and bacterial consortia.

Chemoorganotrophic fungi are especially concentrated in stone crusts. They are able to penetrate into the rock material by hyphal growth and by biocorrosive activity, due to the excretion of organic acids or by oxidation of mineral-forming cations, preferably iron and manganese [4]. Fungal hyphae penetrating the inner stone pores and conidiospores belonging to Penicillium sp. on volcanic stone in the 4 meter-high of the external wall of $3^{\text {rd }}$ sampling point was exhibited

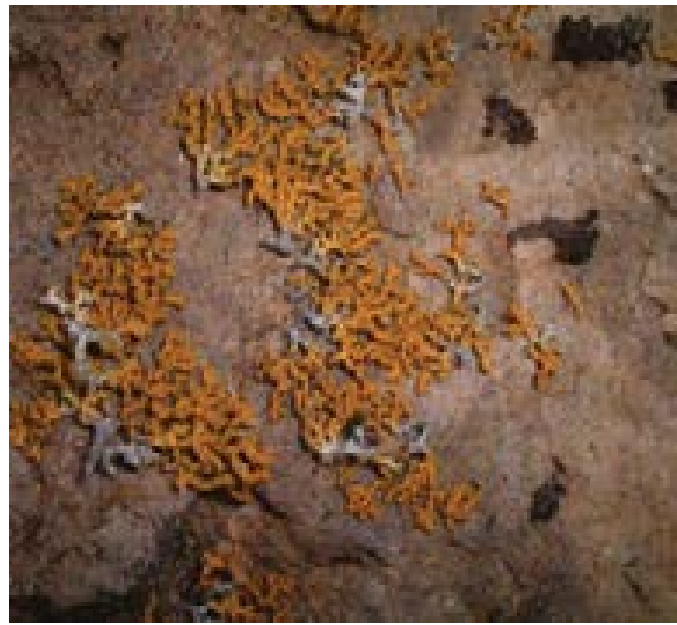

Figure 10: The colonization of Xanthoria elegans on the monastery wall.

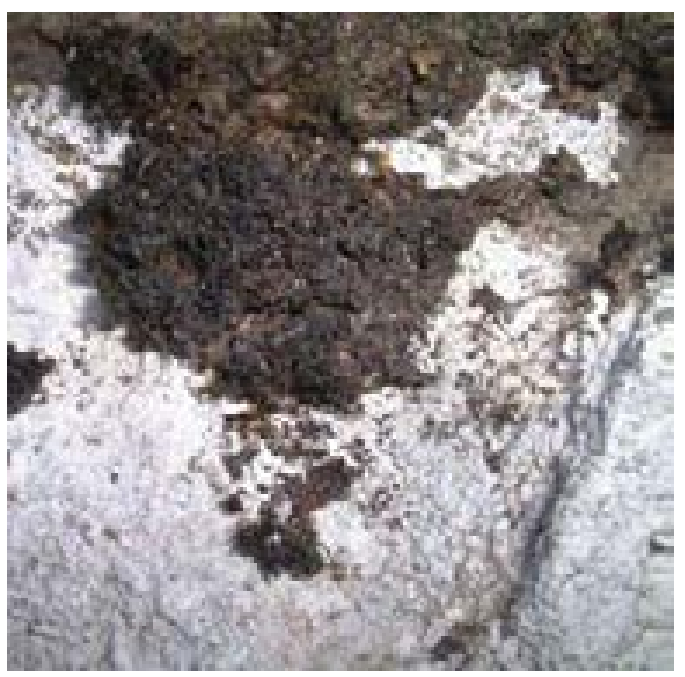

Figure 11: The microbial consortia of Lepraria incana and Dermatocarpon sp.

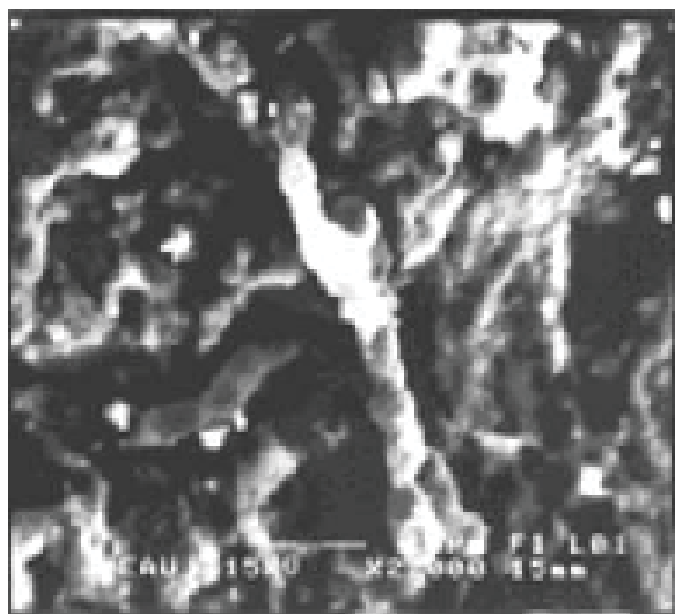

Figure 12: Fungal hyphae and conidiospores belonging to Penicillium $s p$. the inner stone pores.

in Figure 12. SEM images indicate that the microorganisms invading these stone surfaces showed extensive euendolithic destructive activity (Figures 7 and 12).

The growth and metabolic activity of algae, cyanobacteria, and lichens, as well as mosses and higher plants, is regulated by natural parameters such as light and moisture. Simultaneously, stone decay is correlated with the type of stone material and exposure conditions for the monuments, including wind, sunlight and temperature, as well as rain, snow and moisture [4]. In order to access the biological contribution on stone decay, the stone type, the mineralogical composition and the appearance of the microorganisms on the stone surfaces were determined. The elemental analyses of the stone samples of the Sumela Monastery are shown in Table 3. Table 3 shows $\mathrm{Si}, \mathrm{Al}, \mathrm{Ca}, \mathrm{K}, \mathrm{Mg}, \mathrm{Zn}$ and $\mathrm{Nb}$ present in all samples. These elements constitute the main components of the stones. $\mathrm{Si}, \mathrm{Al}, \mathrm{Ca}, \mathrm{K}, \mathrm{Mg}, \mathrm{Zn}$ and $\mathrm{Nb}$ are in the range of about $7-29 \%, 2-8 \%, 1-37 \%, 1-3 \%, 1-2.5 \%, 0.5-$ 3.5 and $1-7.5 \%$ respectively. In addition, significant quantities of $\mathrm{Na}$, 
Citation: Nuhoglu Y, Var M, Koçak E, Uslu H, Demir H (2017) In Situ Investigation of the Biodeteriorative Microorganisms Lived on Stone Surfaces of the Sumela Monastery (Trabzon, Turkey). J Environ Anal Toxicol 7: 506. doi: 10.4172/2161-0525.1000506

Page 9 of 10

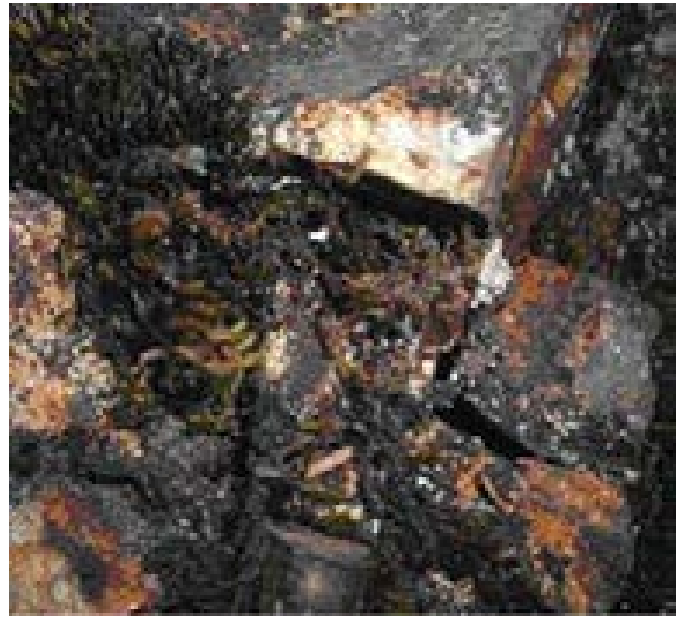

Figure 13: The physical and aesthetically detrimental effects and the stone surface coloring of the monastery stones.

$\mathrm{Mn}$ and $\mathrm{S}$ are present some stones. $\mathrm{Si}, \mathrm{Ca}, \mathrm{K}, \mathrm{Mg}, \mathrm{Zn}, \mathrm{Na}, \mathrm{Mn}$ and $\mathrm{S}$ existence in the Monastery stones is desirable because of contributing to the development of the microorganisms on stone surfaces. Iron and manganese serve as essential elements for stone dwelling microflora, and the presence of exchangeable calcium in the stone plays a constant suitable $\mathrm{pH}$-milieu for the growth of bacteria and fungi $[4,13,16]$.

Chemoorganotrophic bacteria and fungi are often present in the surface biofilms on the stones and use organic substrates such as hydrogen, carbon and an energy source. They commonly excrete complexing biocorrosive organic acid (i.e., oxalic, oxaloacetic, citric, gluconic, glyoxalic, fumaric) or weaken the mineral lattice by the oxidation of metal cations such as $\mathrm{Fe}^{+2}$, or $\mathrm{Mn}^{+2}$. These acids are efficient for rather slowly-solving cations such as $\mathrm{Ca}, \mathrm{Al}, \mathrm{Si}, \mathrm{Fe}, \mathrm{Mn}$ and $\mathrm{Mg}$ from minerals forming stable complexes. It has been shown that biogenic organic acids are considerably more effective in mineral mobilization than inorganic acids and are considered as one of the major damaging agents affecting stone deterioration [4]. The way of deterioration on the stone surface, as a lost of esthetical value, has been seen in Figures 4-13.

As seen in Figure 2, roots of weed and trees are destroying the monuments [23]. Since the climatic conditions become temperate and rainy, the weed, trees and microbial consortia is abundant on the stone surfaces of the Monastery and the environment. Typical examples are shown in Figures 6-9, 11 and 13. In the Sumela Monastery, the colors of stone surface biofilm are frequently changed to brown, caramel, sorrel, white and sometimes black (Figures 8-11 and 13). This is due to the growth of algae and lickens. Growing algae and lickens have cause the aesthetically detrimental effect due to their pigments. The microbial discoloration of stone and rock surfaces has to be considered as a primary biogeophysical impact on the mineral surfaces $[4,15]$.

\section{Conclusions}

The biodeterioration of the Monastery stones is the result of complex microbial interactions in the microbial consortia and not the consequence of the action of a particular group of microorganisms because the climatic condition of this region are suitable for growing of various living (macro and micro) organisms. In situ and SEM observations demonstrated that autotrophic and heterotrophic micro and macro flora, composed of moss, lickens, algae, fungi, bacteria and even herb and trees settled on the walls of Sumela Monastery. Among them, acid-producing bacteria can cause biodeterioration due to metabolic acids biosolubilizing the stone. Phototrophic microorganisms, algae and lickens, induce biogeophysical formation of patina and crusts. These deposits enhance physical stress and also cause biogenic coloration of the stone, with consequent aesthetic loss. While lichens and mosses can cause deterioration of the stone by chemical rather than mechanical effects [8]. There may be additive biodeteriorative effect of the other microorganisms like cyanobacteria and etc., but we didn't searched its. Similar researches demonstrated that cyanobacteria is a component of stone deteriotation $[4-8,21,24,25]$.

Besides the evident influence of light in distribution of phototrophic microorganisms, biofilms showed preference for different type of materials [15]. The Sumela Monastery was built two originated stones: volcanic such as volcanic lava, andesite and trachide, and sediment as travertine. Table 3 shows that, volcanic and sediment analyzed materials were relatively heterogeneous in chemical composition but showed some important similarity concerning concentration in silicone, aluminum, magnesium and the other (carbon+hydrogen+oxygen) elements in volcanic stones. While sediment material is also abundant in calcium, volcanic materials showed the highest concentration of silicone and aluminum. The highest concentration of other (carbon+hydrogen+oxygen) elements in volcanic stones may be indicated organic mass belonging to the high moss, algal and lichen cells. Under similar light conditions, phototrophic microorganisms tend to colonize mainly calcareous materials. This is probably due to the chemical availability of calcium from soluble carbonate that can be a source for cyanobacterial sheath formation [15]. On the contrary of this general rule, the analysed materials in the sumela monastery, phototrophic microorganisms presented the highest abundance of volcanic stone because volcanic materials used in external walls and they exposed to direct sunlight. The sediment materials were used as internal architectural building materials of the room-door, window domes and fresco for easy cutting peculiarities.

The sum up: Urbani [26] said in the paper that “... at a time when man begins to feel the ominous historical novelty of the destruction of his own environment, certain values, like ancient art, demonstrate how the potential of human activity can integrate rather than destroy the beauty of the world" [27]. Unfortunately, we are sorry to say that the marvelous architectural monuments, the Sumela Monastery, was plundered many times by the robbers of historical-heritages belonging to various nations because this historical buildings was not conserved righteously due to placed in the solitary valley away from men. Simultaneously it was exposed to the biodeteriorative effects of the mentioned micro/macro-organisms. However the biodeteriorative effect of microorganisms is more significant on stones of the Sumela Monastery, we see that the man, as a plundering points, is the most destructive agents (see Figures 4 and 5) on the historical building among all of the deteriorative factors.

\section{Acknowledgements}

We thank to Professor Dr. Ihsan Efeoglu and research assistant Ferhat Bulbu from the Department of Mechanical Engineering at Ataturk University for supplying the SEM-EDS analyses. We thank to Prof. Dr. Ali Aslan from the Kazım Karabekir Education faculty at Atatürk University for the catologial work.

\section{References}

1. Kumar A, Kumar AV (1999) Biodeterioration of Stone in Tropical Environments In: Neville A (ed.), J Paul Getty Trust, USA, pp: 1-2.

2. de los Ríos A, Galván A, Ascaso C (2004) In situ microscopical diagnosis of 
Citation: Nuhoglu Y, Var M, Koçak E, Uslu H, Demir H (2017) In Situ Investigation of the Biodeteriorative Microorganisms Lived on Stone Surfaces of the Sumela Monastery (Trabzon, Turkey). J Environ Anal Toxicol 7: 506. doi: 10.4172/2161-0525.1000506

biodeterioration processes at the convent of Santa Cruz la Real, Segovia, Spain. Int Biodet \& Biodeg 54: 113-120.

3. Kuhl D, Bangert F, Meschke G (2004) Coupled chemo-mechanical deterioration of cementitious materials. Part I: Modeling. International Journal of Solids and Structures 41: 15-40.

4. Warscheid T, Braams J (2000) Biodeteriration of stone: a review. Int Biodet \& Biodeg 46: 343-363.

5. Nuhoglu Y, Oguz E, Uslu H, Ozbek A, Ipekoglu B, et al. (2006) The accelerating effects of the microorganisms on biodeterioration of stone monuments under air pollution and continental-cold climatic conditions in Erzurum, Turkey. Sci Total Environ 364: 273-283.

6. Nowicka-Krawczyk P, Żelazna-Wieczorek J, Otlewska A, Koziróg A, Rajkowska $\mathrm{K}$, et al. (2014) Diversity of an aerial phototrophic coating of historic buildings in the former Auschwitz II-Birkenau concentration camp. Science of the Total Environment 493: 116-123.

7. Miller AZ, Sanmartín P, Pereira-Pardo L, Dionísio A, Saiz-Jimenez C, et al. (2012) Bioreceptivity of building stones: A review. Sci Total Environ 426: 1-12.

8. Mandal S, Rath J (2013) Algal colonization and its ecophysiology on the fine sculptures of terracotta monuments of Bishnupur, West Bengal, India. Int Biodet \& Biodeg 84: 291-299.

9. Cennamo P, Montuori N, Trojsi G, Fatigati G, Moretti A (2016) Biofilms in churches built in grottoes. Sci Total Environ 543: 727-738.

10. Sanmartín P, Vázquez-Nion D, Arines J, Cabo-Domínguez L, Prieto B (2017) Controlling growth and colour of phototrophs by using simple and inexpensive coloured lighting: A preliminary study in the Light4Heritage project towards future strategies for outdoor illumination. Int Biodet \& Biodeg 122: 107-115.

11. Caneva G, Gori E, Montefinale T (1995) Biodeterioration of monuments in relation to climatic changes in Rome between 19-20th centuries. Sci Total Environ 167: 205-214.

12. Delalieux F, Cardell V, Todorov V, Dekov V, Van Grieken Y (2001) Environmental conditions controlling the chemical weathering of the Madara Horseman monument, NE Bulgaria. Journal of Cultural Heritage 2: 43-54.

13. Saiz-Jimenez C (1997) Biodeteriration vs biodeterioration: the role of microorganisms in the removal of pollutants deposited onto historic buildings. Int Biodet \& Biodeg 40: 225-232.

14. Caneva G, Bartoli F, Ceschin S, Salvadori O, Futagami Y, et al. (2015) Exploring ecological relationships in the biodeterioration patterns of Angkor temples (Cambodia) along a forest canopy gradient. Journal of Cultural Heritage 16: 728-735.

15. Sanchez-Moral S, Luque L, Cuezva S, Soler V, Benavente D, et al. (2005) Deterioration of building materials in Roman catacombs: The influence of visitors. Sci Total Environ 349: 260-276.

16. Tomaselli L, Lementi G, Bosco M, Tiano P (2000) Biodiversity of photosynthetic micro-organisms dwelling on stone monuments. Int Biodet \& Biodeg 6: 251258.

17. Uzun A (2002) Altındere vadisi (Macka-Trabzon) Orman vegetasyonu florası. MSc Thesis, KTU Fen Bilimleri Enstitusu, p: 112.

18. Clauzade G, Roux C (1985) Likenoj de Okcidenta Europo. Ilustritadeterminlibro. Bulletin of Society of Botanical Centre - Quest 7: 893.

19. Bourrelly P (1970) Les algues d'eau douce. Initiation à la sistematique III. Les algues bleus et rouges, les Eugléniens, Péridiniens et Cryptomonadines. N Boubée, Paris, p: 512.

20. Uchida E, Ogawa Y, Maeda N, Nakagawa T (2000) Deterioration of stone materials in the Angkor monuments, Cambodia. Engineering Geology 55: 101112.

21. Ascaso C, Wierzchos J, Souza-Egipsy V (2002) In situ evaluation of the biodeteriorating action of microorganisms and the effects of biocides on carbonate rock of the Jeronimos Monastery (Lisbon). Int Biodet \& Biodeg 49: $1-12$.

22. Nuhoglu $Y$ (2004) The biodeteriorative action of microorganisms and the effects on stone monuments under air pollution and continental-cold climatic condition In Erzurum, Turkey. Fresenius Environmental Bulletin 13: 591-599.

23. Mishra AK, Jain KK, Garg KL (1995) Role of higher plants in the deterioration of historic buildings. Sci Total Environ 167: 375-392.

24. Videla HA, Guiamet PS, de Saravia SG (2000) Biodeterioration of Mayan archaeological sites in the Yucatan Peninsula, Mexico. Int Biodet \& Biodeg 46: 335-341.

25. Adamo $P$, Violante $P(2000)$ Weathering of rocks and neogenesis of minerals associated with lichen activity. Applied Clay Science 16: 229-256.

26. Urbani G (1996) The science and art of conservation of cultural property. In Price NS, Talley MK, Vaccaro AM (eds.), Historical and Philosophical Issues in the Conservation of Cultural Heritage, The Getty Conservation Institute, Los Angeles, USA, pp: 445-450.

27. Pope GA, Meierding TC, Paradise TR (2002) Geomorphology's role in the study of weathering of cultural stone. Geomorphology 47: 211-215. 